\title{
Legemiddelbruk og hoftebrudd
}

\section{Uheldig legemiddelbruk er utbredt hos eldre og involverer ofte psykotrope legemidler. Bruk av anbefalte psykotrope midler er forbundet med økt risiko for hoftebrudd.}

Eldre er storforbrukere av legemidler og ekstra sårbare for negative legemiddeleffekter. Psykotrope legemidler er veletablerte risikofaktorer for fall. Hoftebrudd er en fryktet konsekvens.

Mitt doktorarbeid er basert på to studier. I den første undersøkte vi legemiddelbruk og forskrivningskvalitet hos akuttinnlagte eldre. Uhensiktsmessig forskrivning var utbredt og involverte ofte psykotrope legemidler. Deretter koblet vi data fra Reseptregisteret og Nasjonalt hoftebruddsregister og fulgte alle i Norge over 60 år (>900 000 personer) i seks år.

Bruk av alle typer antidepressiver, hypnotika og sedativer var forbundet med økt risiko for hoftebrudd sammenliknet med ikke-bruk. Mer spesifikt fant vi en nær doblet risiko ved bruk av selektive seretonin- reopptakshemmere (SSRI) og andre antidepressiver med liknende virkemåte. Vi fant ingen støtte for at korttidsvirkende benzodiazepiner var sikrere enn langtidsvirkende. Videre var det en overhyppighet av nattlige brudd ved bruk av zopiklon og zolpidem.

Samlet understreker funnene viktigheten av bevisst forskrivningspraksis. Psykotrope legemidler er hyppig brukt, men har begrenset effekt og høy forekomst av uønskede effekter hos eldre. Eventuell forskrivning bør derfor tilpasses den enkelte og følges nøye. Hvis mulig bør man velge ikkefarmakologiske tiltak. Funnene våre bør undersøkes nærmere i kliniske studier.

Marit Stordal Bakken

marit.bakken@uib.no

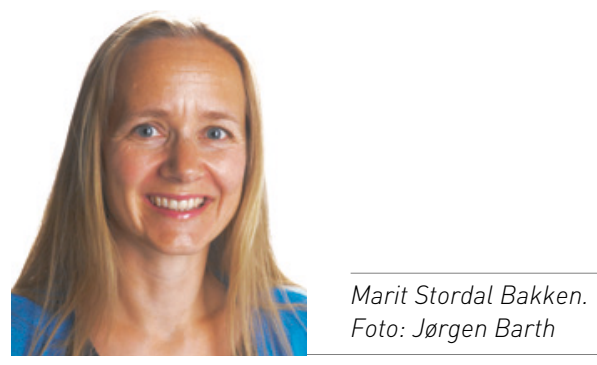

Disputas

Marit Stordal Bakken disputerte for ph.d.graden ved Universitetet i Bergen 11.11. 2015. Tittelen på avhandlingen er Potentially inappropriate drug use and hip fractures among older people - pharmacoepidemiological studies.

\section{Utprøvning av ny hofteprotese i geitemodell}

\author{
Ved utprøvning av ny hofteprotese i en geitemodell ble det funnet signifi- \\ kante forbedringer ved nye utforminger av protesene.
}

Omtrent $15 \%$ av hofteproteseoperasjoner i Norge er revisjoner. En revisjon kan ofte være mer omfattende og tidkrevende enn det første inngrepet. En ideell protese skal sitte godt fast og vare lenge, samtidig som den bør være enkel å revidere hvis det skulle bli nødvendig. Vi har i prosjektet sett på om disse hensynene kan kombineres i en ny utforming av hofteproteser.

Vi opererte totalt 47 geiter i høyre hofte med en ny totalprotese. Disse geitene ble observert i seks måneder etter operasjonen, for så å bli avlivet. Styrken av innfestingen ble målt ved å dra protesen ut av beinet. Det ble gjort histologiske analyser av beinpåveksten mot implantatet. Vi undersøkte to overflatebelegg for å finne hvilket som kunne bedre beinveksten.
Den nye utformingen gjorde at protesen satt godt fast og at den ble noe lettere å fjerne ved utboring. Forskjellen var mindre enn man kunne vente ut fra en teoretisk betraktning. Det var noe ulik innfestingskraft ved de to beleggene som var undersøkt.

Studien viser at det er komplisert og krevende å utforme nye hofteproteser fordi en rekke mekaniske og biologiske faktorer spiller sammen. Prinsippene for denne hofteproteseutformingen kan danne et grunnlag for ytterligere raffinering med tanke på bruk hos mennesker.

\section{Knut Harboe}

harboe@me.com

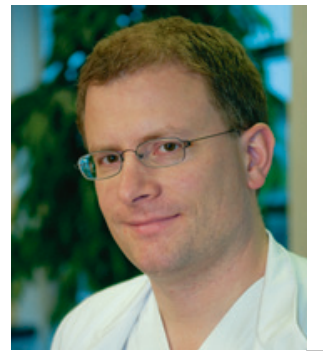

Knut Harboe. Foto: Svein Lunde

\section{Disputas}

Knut Harboe disputerte 20.8. 2015 for ph.d.graden ved Universitetet i Bergen med avhandlingen Developing a novel femoral stem in hip arthroplasty - an innovation process using a weight-bearing animal model. Prosjektet har vært en innovasjonsprosess i samarbeid med Aarbakke AS på Bryne. 